\title{
Develop Your Own Florida Olive IPM Plan ${ }^{1}$
}

\section{Morgan Byron, Eleanor Phillips, and Jennifer L. Gillett-Kaufman²}

\section{Introduction}

For a Florida olive industry to be financially productive, the olive trees need to be in optimal health to produce an optimal yield. Nutrition, irrigation, tree variety selection and location, and pest issues will be challenges to overcome given Florida's hot, humid climate. Olive trees are naturally found in warm, arid environments, so their needs and ideal growing conditions are still being studied in Florida for crop-production purposes. All recommendations in this guide are based on existing scientific literature about olivegrowing operations in the United States with information from Florida emphasized when available.

Healthy, well-maintained trees (Figure 1) will require fewer inputs in terms of pest management. For the olive trees to remain in optimal health and produce optimal yield, there are many things to consider, namely nutrition, irrigation, tree variety and location, and pest issues. The cornerstone to any successful integrated pest management (IPM) plan is caring for plants in a way that promotes optimum plant health. Early detection and suppression of pests will also reduce unnecessary pesticide applications. This guide touches on some aspects of olive tree health that will help your trees develop their natural resistance to pests and pathogens. At the end of this guide there is a monthly care and observation schedule to help you know when you should begin scouting for key pests and when important grove-management decisions should be made.

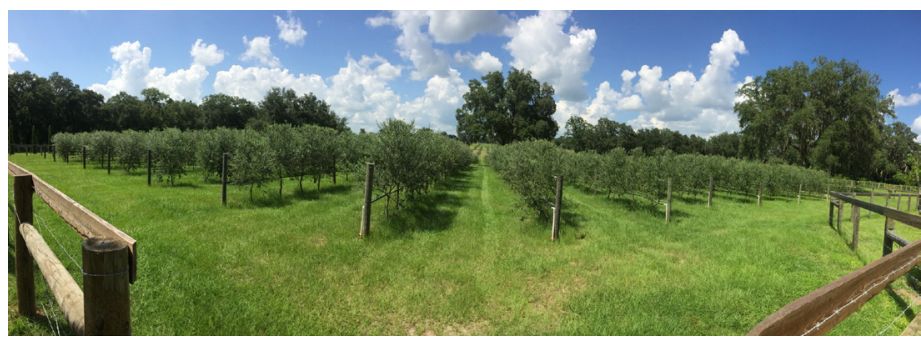

Figure 1. A four-year-old olive grove in north central Florida. Credits: Morgan Byron

To stay up-to-date on information as it arises, consult the University of Florida Institute of Food and Agricultural Sciences (UF/IFAS) Electronic Data Information Services (EDIS). All EDIS publications are peer reviewed and updated every three years and should be revisited often for new information. This guide is a supplement to several existing factsheets that are available on EDIS. Please look over this information carefully as you consider management decisions.

\section{Site Considerations Ultimate Grow Goals}

- Determine plant spacing and row spacing that will be best for your site conditions

- Achieve flower bud development (need healthy trees and appropriate winter dormancy)

- Achieve flower bud break (need sufficient chill hours)

- Ensure flower survival (need not-too-hot weather and not-too-severe spring rains)

1. This document is ENY990, one of a series of the Entomology and Nematology Department, UF/IFAS Extension. Original publication date August 2019. Visit the EDIS website at https://edis.ifas.ufl.edu for the currently supported version of this publication.

2. Morgan Byron, Doctor of Plant Medicine graduate; Eleanor Phillips, student, Doctor of Plant Midicine Program; and Jennifer L. Gillett-Kaufman, Extension scientist, Entomology and Nematology Department; UF/IFAS Extension, Gainesville, FL 32611.

The Institute of Food and Agricultural Sciences (IFAS) is an Equal Opportunity Institution authorized to provide research, educational information and other services

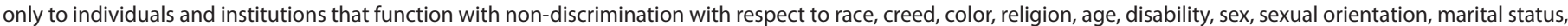

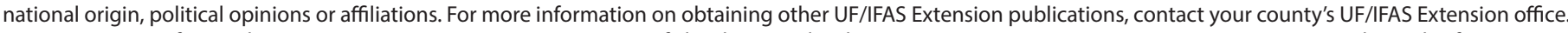
U.S. Department of Agriculture, UF/IFAS Extension Service, University of Florida, IFAS, Florida A \& M University Cooperative Extension Program, and Boards of County Commissioners Cooperating. Nick T. Place, dean for UF/IFAS Extension. 
- Ensure flower pollination (need a mix of cultivars nearby)

- Ensure fruit formation (need correct nutrition and no pathogens)

- Protect trees from winter freeze damage (ensure winter dormancy by stopping fertilizer and irrigation in fall)

Olives are alternate bearing trees, which means that trees will produce a measurably larger harvest of olives in alternate years.

For olives, nitrogen $(\mathrm{N})$, potassium $(\mathrm{K})$, and boron $(\mathrm{B})$ are the nutrients most likely to be deficient, though all essential nutrients are needed for healthy growth and should be maintained within their optimal ranges. Refer to the Guide to Olive Tree Nutrition in Florida for complete information on olive fertility needs in Florida: https://edis.ifas.ufl.edu/ ag405.

\section{Climate}

\section{Major Climate Considerations}

- Olive trees cannot survive temperatures below $10.5^{\circ} \mathrm{F}$

- Trees will be damaged if temperatures fall below $22^{\circ} \mathrm{F}$, especially if dormancy is interrupted by fertilizing or irrigating after September

- New growth (young shoots) and olives (fruit) are damaged at temperatures below $29^{\circ} \mathrm{F}$

- Unseasonal freeze events (late autumn, early spring) or winter warmth will decrease overall cold tolerance

\section{Chilling accumulation takes place between $32^{\circ} \mathrm{F}$ and}

$47^{\circ} \mathrm{F}$. Hours during which the air temperature stays between $32^{\circ} \mathrm{F}$ and $47^{\circ} \mathrm{F}$ are an olive tree's chill hours. The tree needs sufficient chill hours to form floral buds. Floral buds begin to form in winter as unseen metabolic changes are occurring. Their development during this time is crucial to budbreak in the spring.

Severe freezes are not good for olives because they can damage tissue that is very young or trees that are not fully dormant, but olive trees do need some chilling. What exactly does chilling do? It is likely responsible for controlling levels of growth regulators like gibberellins and abscisic acid within the buds (Ferguson 2015). Floral bud differentiation begins in early February (Ferguson 2015), and chilling should occur before this event. Though Florida winters are mild, it is theoretically possible to accumulate the 200-300 chill hours required for an olive crop in some parts of Florida. Temperatures above or below the chilling accumulation range in winter are known to reduce floral bud formation (Ferguson 2015, University of California
Davis). Specifically, prolonged temperatures of about $75^{\circ} \mathrm{F}$ in winter will negatively affect flowering in 'Arbequina' (Malik and Bradford 2006).

\section{Wind Storm or Hurricane Damage}

Hurricanes can present a problem in olive groves in Florida, as can thunderstorms with high winds throughout the year. These storms are most prevalent in the summer. High winds, combined with frequent rainfall softening the ground, can cause trees to tip over (Figure 2). After a hurricane, trees may need to be moved into the upright position and tied to metal/wooden supports or new poles in the ground (PVC, wood, bamboo for young trees, and stakes with tie-downs for older trees).

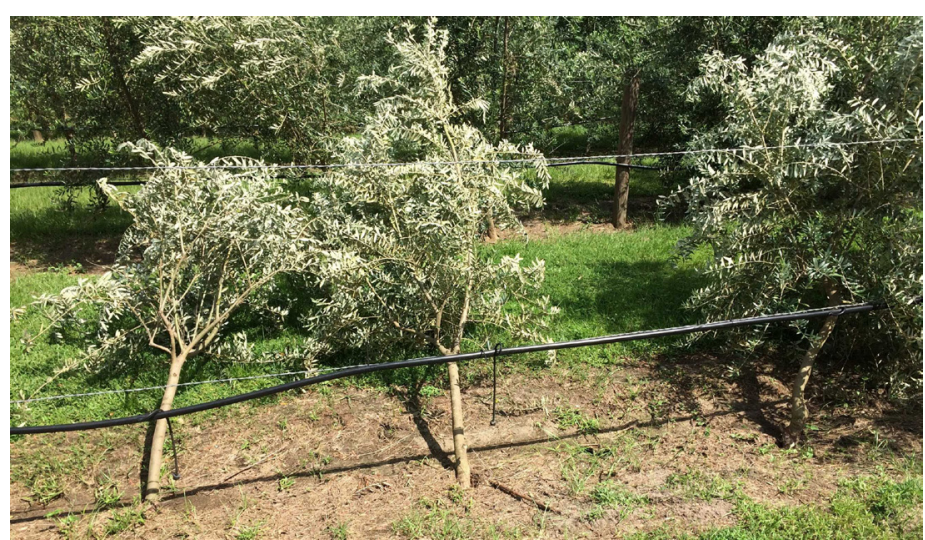

Figure 2. Five-year-old olive tree knocked over by tropical storm winds in north central Florida.

Credits: Morgan Byron

Trees that are no longer upright can have their root systems damaged, which can kill the tree. After a storm, make every effort to right your olive trees and secure them to supports within a 24- to 48 -hour period. Fortunately, summer storms will occur after flower and fruit set and are not likely to decrease yield unless trees are lost. Weather damage can also expose the trees to disease pressure if damage to the plant tissue creates openings for pathogens to enter. Use preventative copper fungicide sprays if trees are damaged and pathogens are known to occur in the grove. Reapply copper as necessary according to label directions.

For more information on preparing and protecting trees from hurricane damage, please refer to Preparing for and Recovering from Hurricane and Tropical Storm Damage to Tropical Fruit Groves in Florida at http://edis.ifas.ufl.edu/ hs287. 


\section{Pruning}

Olive trees fruit on the growth that appeared in the spring-summer of the previous year, so pruning back this new growth will reduce yield. It is better to prune trees by removing branches in the middle of the canopy from the base. Tipping the branches (cutting branches at the ends) is not recommended, as this is usually the one-year-old growth that will produce the olives. If this becomes too confusing, prune in the summer so that fruiting branches are more obvious and can be avoided. Pruning can be done any time during the year, but February to May is preferable because the growth rate of olives trees is much slower at this time.

\section{Fertilizers and Pesticides}

Many different chemicals may be required throughout the course of the year. In general, fertilizers and pesticides can be purchased from a garden supply store, ordered through a local vendor or sales representative, or purchased online. Some insects can develop resistance to insecticides, so rotate products between chemical classes when possible. The bulleted list below includes some chemical products that will likely be of use for olive grove managers in Florida. Scout and monitor for pests regularly and take action immediately if you spot pests so that you can limit your use of pesticides and purchase them only as-needed.

- Bacillus thuringiensis, also known as $\mathrm{Bt}$, is a biologically based insecticide used to treat some insect pests, specifically smaller caterpillars. This product is usually found in a liquid formulation and can be sprayed directly onto affected plants. Florida olive grove managers have used $\mathrm{Bt}$, and it was effective against olive shootworm. All Bt products contain more or less the same ingredients, so if you wanted to change brands (due to price or availability, for example), that should not be a problem-just always follow label instructions.

- Horticultural oil is a light vegetable oil or petroleumbased oil that is used to smother small pests that are difficult to treat with other types of insecticides. Typically, these oils are used for mites, thrips, or scale insects. They are usually formulated as a concentrate that emulsifies in water and can be applied as a spray. Horticultural oil can also be purchased online or at garden supply centers. These oils can only be applied under certain weather conditions: always consult the label. Applying this oil when temperatures are high can severely damage leaves and small branches.
- Copper fungicides are a pesticide that restricts the growth of fungal pathogens. Copper can be applied preventatively (before disease symptoms are found in the field) as a liquid spray formulation. There are many different types of copper fungicides that may be used, and they are widely available. Always read label directions to make sure the product is labeled for use on olive, and apply as directed.

- Fertilizers should be used after a soil test indicates your trees' fertilizer needs. All UF fertilizer recommendations should be followed, and local ordinances for fertilizer use should be followed. For assistance determining your fertilizer needs, seek guidance and assistance with soil testing from your local county UF/IFAS Extension Office. Refer to the Guide to Olive Tree Nutrition in Florida for complete information on olive fertility needs in Florida: https://edis.ifas.ufl.edu/ag405

It is important to keep records of what chemicals you apply and at what rate and volume, as well as where, and when they were applied. Record-keeping is an important part of an integrated pest management plan and can inform management decisions into the future. The Importance of Keeping Pesticide Records https://edis.ifas.ufl.edu/pi246 provides guidance on what records to keep. See especially the section on Agricultural Pest Control.

\section{Weed Control}

The grass between rows of olive trees should be cut to a height of 4 inches, and no more than $1 / 3$ of the grass blade should be removed at a time (for Bahiagrass rows). Cutting any shorter than this will reduce the grass's vigor and allow weeds to encroach. Keeping the grass between rows healthy is a simple way to reduce weed populations in the field.

To remove weeds between trees (Figure 3), you can rely on mechanical removal with a weed-whacker. This is an acceptable method of weed removal, but workers are advised to use caution and avoid hitting the trunks of the olive trees with the weed whacker. Damage to the olive tree trunks can stress the trees and increase their susceptibility to pathogens. New employees should be trained and supervised to ensure the trees are not damaged. Weeds should be managed before seeds form to reduce future weed problems.

\section{Pests and Pathogens}

For a more complete overview of pests and pathogens on olive, including potential invasive species of concern, please refer to Pests and fungal organisms identified on olives (Olea europaea) in Florida available at https://edis.ifas.ufl.edu/ in1046. 




Figure 3. A two-year-old olive tree surrounded by weeds in north central Florida.

Credits: Morgan Byron

\section{Insects}

\section{BLACK SCALE, Saissetia oleae}

These small insects attach to the leaves and twigs of the olive trees, anchor themselves there, and feed on plant sap (Figure 4). Their feeding produces honeydew as a by-product, and the honeydew can attract sooty mold and ants. The presence of ants or dark, mildew-like growth on the trees are signs of a scale infestation. The best management tactic for this insect pest is early detection and hand removal. Horticultural oil sprays are also used to combat scale infestations, but they can only be applied under cool temperatures. Appropriate ant management can reduce scale populations as can ensuring that new plantings are free of black scale before bringing them to the field. No chemical control is needed for sooty mold.

\section{FIRE ANTS, Solenopsis invicta}

Fire ants can pose a nuisance in a variety of landscapes, including fruit orchards. Fire ants form mounds that can extend deep belowground and contain thousands of individual ants, making them difficult to control. Ants can cause a variety of problems in an olive grove: protecting populations of honeydew-secreting insect pests (like black scale) on trees, tunneling beside trees and disrupting their root systems or irrigation lines, and inflicting painful stings to those working in the field.

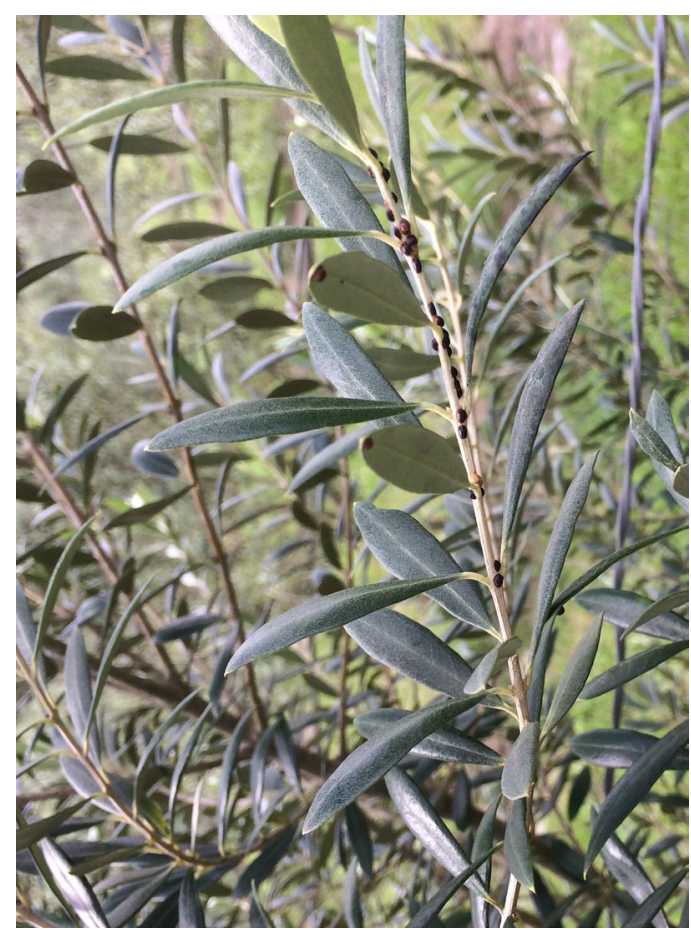

Figure 4. Black scale and sooty mold on an olive tree. Credits: Morgan Byron

One of the simplest and most effective ways to reduce fire ant populations in the field is to apply fire ant bait granules with insecticide. These granules are most effective when used preventatively, before ant mounds become prevalent in the field. Granular baits work better as a preventative measure because they are slow-acting once applied. For a more direct and fast-acting approach, many insecticides can be used as a drench on fire ant mounds. It is very important to thoroughly read the label directions before applying any insecticide - the product must be labeled for use on the target pest and must be approved for use in olive groves.

For a perennial crop, like olives, fire ant control treatments are best applied in the fall or after harvesting when the insects are active but the fruit has been harvested for the year.

For more specific information on fire ants and control baits and drenches, consult the University of Florida Featured Creatures article on red imported fire ant and these EDIS Articles.

\section{OLIVE SHOOTWORM, Palpita persimilis}

The olive shootworm is a very small, green caterpillar that feeds on the new foliage found on olive tree shoots (thus the name, Figure 5). The caterpillars themselves are difficult to see initially; the most obvious symptom is leaf desiccation and dieback on the shoot tips due to their feeding. They 
also make webs within the leaves they feed on, and, characteristically, they produce a large amount of small black frass (excrement). Scout for this pest once new growth occurs after pruning. You can achieve quick control of this pest with the use of Bt foliar sprays while it is still a caterpillar.

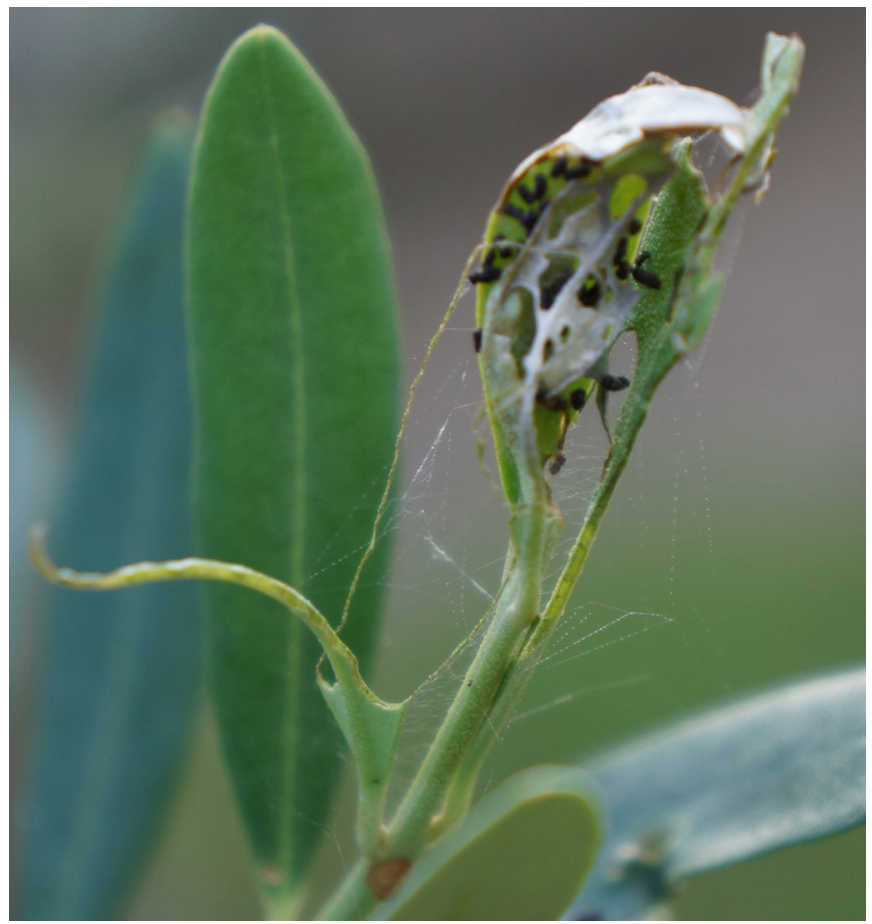

Figure 5. The tip of an olive branch with webbing and frass (feces) of the olive shootworm.

Credits: Eleanor Phillips

\section{FLOWER THRIPS, Frankliniella spp.}

Flower thrips are tiny insects that feed on flowers of a wide variety of plants (Figure 6). The species most common in Florida olive groves is a tiny yellow thrips called Frankliniella bispinosa. To detect these insects in your grove, you can tap branches with open flowers onto a white piece of paper and use a hand lens to see if any of these minute insects are present. Flower thrips may potentially prevent pollination and subsequent fruit set by causing damage to olive flowers, so scouting for these pests as soon as flowers begin to open in early spring is very important. Monitoring for flower thrips using blue colored sticky card traps is most effective in Florida olive groves. Since olives are such a new crop for Florida, many current groves have not been established long enough for the trees to be at their full productive potential, which is typically 7 to 10 years. This means many Florida groves have not yet experienced years of heavy flowering and subsequent fruiting, so the economic injury level of flower thrips in Florida olive remains to be determined. If you find flower thrips in large numbers in your groves during flowering, use only reduced-risk insecticides labeled for olives and thrips.

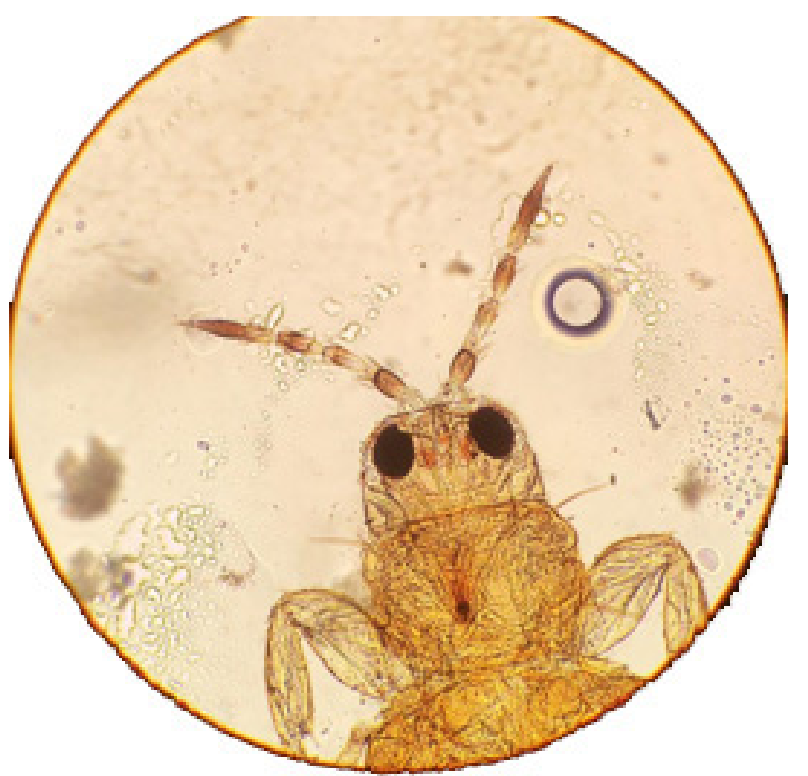

Figure 6. Magnified view of thrips collected from olive in Florida. Credits: Eleanor Phillips

\section{HORNWORM, Manduca rustica}

The caterpillar life stage of the native moth species Manduca rustica has been found to quickly defoliate young olive trees in Florida (Figure 7). The caterpillar is called a hornworm because of the characteristic curved, hornlike protrusion on the end of its abdomen. Hornworms are green with light yellow diagonal stripes. Eggs of the hornworm have been found laid singly on olive leaves, and the caterpillars voraciously feed on olive leaves and grow to be around eight $\mathrm{cm}$ in length. Growers have reported feeding as early as May, and we recommend scouting for eggs and caterpillars beginning in April. Immediate control measures are recommended upon detection of hornworms because they cause rapid and extensive damage. Some hornworms have been detected with parasites in their egg and caterpillar form, so the use of reduced-risk pesticides is recommended.

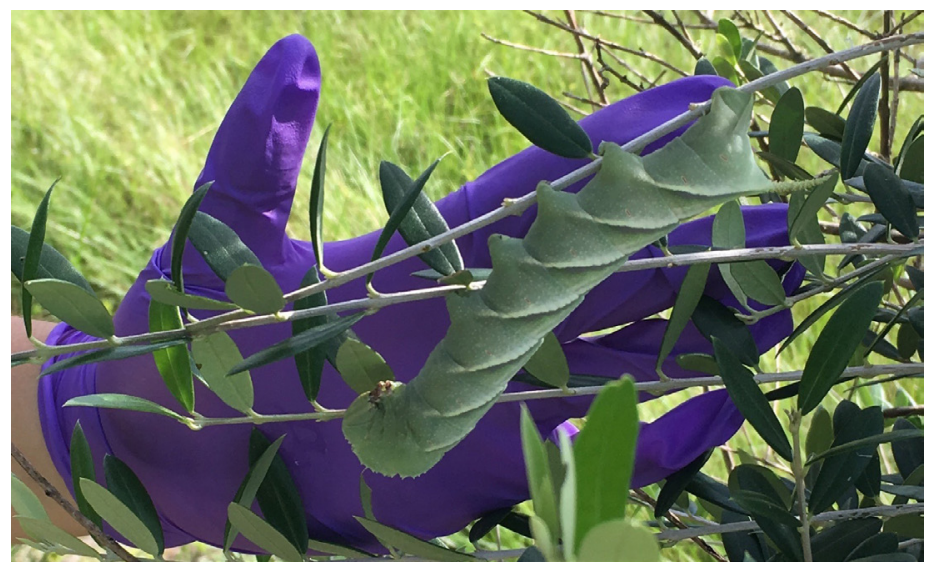

Figure 7. A hornworm caterpillar feeding on olive in Florida. Credits: Eleanor Phillips 


\section{STINK BUGS, FAMILY PENTATOMIDAE AND LEAFFOOTED BUGS, FAMILY COREIDAE}

Stink bugs are the common name for many plant-feeding insects that produce a defensive, smelly chemical when disturbed (Figure 8 ). Leaffooted bugs are typically more elongated than stink bugs, and have characteristic hind legs that often are enlarged and described as leaf-like in shape. Stink bugs and leaffooted bugs remain in their adult life stage in winter months and are most active April through September in Florida olive groves. Although stink bugs and leaffooted bugs damage olive leaves and fruit, the economic threshold for their control in Florida olive is unknown because many groves have not yet reached full productive potential. Scouting for these bugs beginning in April is recommended, and monitoring should be done throughout fruit development in summer months and harvest, which is typically in September. Using traps that are visually and chemically attractive to stink bugs such as yellow pyramid traps baited with lures is a good way to suppress populations of stink bugs. These bugs are very mobile, and insecticides are not very effective control measures for them. There are many beneficial predatory stink bug species and other insects that are beneficial and appear very similar to pest stink bugs. If you are unsure whether you have a pest or beneficial stink bug, Stink Bugs and Leaffooted Bugs Are Important Fruit, Nut, Seed, and Vegetable Pests is useful and available here: http://edis.ifas.ufl.edu/in534.

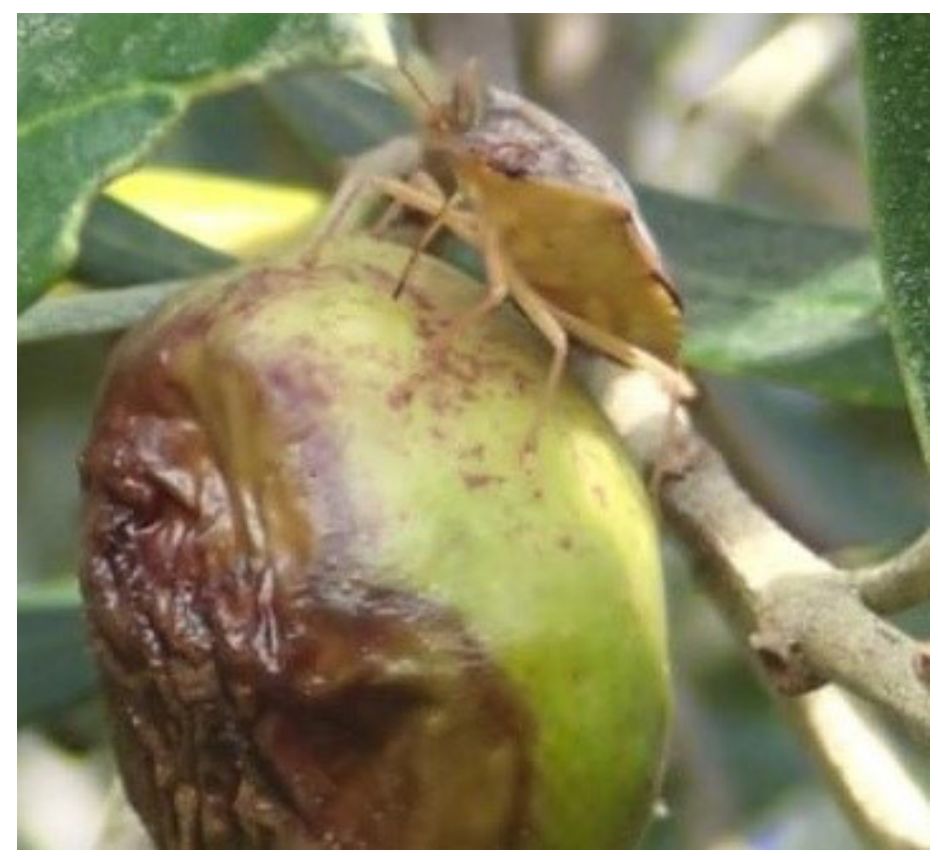

Figure 8. A stink bug feeding on olive in Florida. Credits: Sandra Allan

\section{GLASSY-WINGED SHARPSHOOTER, Homalodisca vitripennis}

The glassy-winged sharpshooter is a common, native insect pest of Florida belonging to a group of insects called leafhoppers. It is a known vector of the bacterial plant pathogen Xylella fastidiosa subspecies fastidiosa, which causes disease in grapevines. Insects similar to the glassy-winged sharpshooter have been identified in Italian olive groves spreading another subspecies of Xylella fastidiosa that causes olive quick decline, a serious disease that kills the tree. The glassy-winged sharpshooter is known to feed on Florida olive and is found most frequently on yellow sticky card traps in Florida olive groves. If the subspecies of Xylella fastidiosa that causes olive quick decline is introduced to Florida, the glassy-winged sharpshooter could spread the disease throughout the state because it is a very mobile insect. Monitoring for this insect with yellow sticky cards traps throughout the growing season is recommended.

\section{GRASSHOPPERS AND KATYDIDS, ORDER ORTHOPTERA}

Grasshoppers and katydids are occasional pests of olive, and damage from these insects looks like large bites have been taken from the outer edges of the leaves. The characteristic damage is observed infrequently; however, when weedy hosts are prevalent in groves, these insects are frequently found encroaching on olive trees. In this scenario, the pests may move from the weeds to the trees more frequently due to the increased proximity of the preferred host species to the olives. Good weed management is the best way to prevent foliar feeding damage from these insects.

\section{POTENTIALLY INVASIVE INSECTS Olive Fruit Fly, Bactrocera oleae}

The olive fruit fly, Bactrocera oleae, is a pest of olive fruit that is not currently present in Florida olive groves; however, this pest is sometimes intercepted in olive plant material that is imported from other olive-growing regions, especially California. The olive fruit fly is found in every olive-growing region of the world besides the southeastern United States, and it causes the most economic damage in olive systems worldwide. The female olive fruit fly causes damage to developing fruit by laying its eggs into the fruit. The eggs then hatch within the fruit, and the emerged maggots will eat their way out of the fruit and drop to the soil to pupate. The holes left in the fruits from the egg laying and emerging maggots leave openings for secondary pests such as fungal diseases to further deteriorate the fruit quality. There is a very low threshold for olive fruit fly in the United 
States for olives produced for oil, so control of the fly is almost always warranted to ensure populations are as low as possible. It is highly advised that olive mills in the southeast not import fruit for processing from areas where the olive fruit fly is known, that they screen all fruit carefully, and that they take measures to ensure no adult flies move into nearby olive groves. A good way to monitor for the olive fruit fly in your olive grove is to use yellow sticky card traps that are baited with food and chemical lures specifically designed to attract olive fruit flies. For best monitoring, change to new sticky traps and lures every month from fruit development through harvest. If you believe you have found an olive fruit fly on a sticky card or other monitoring method in your olive groves, please send the sample to the Florida Department of Plant Industry for positive identification. For more information on the olive fruit fly, please refer to this Extension document: https://entnemdept.ifas. ufl.edu/creatures/fruit/tropical/olive_fruit_fly.htm.

\section{Pathogens}

\section{Botryosphaeria BLIGHT/WILT}

Botryosphaeria dothidea is a common fungal pathogen that can be found living on the surfaces of plants. It is very prevalent in the environment and does not cause a problem until it can invade a plant host through a wound (such as that made by pruning, weather damage, or an insect feeding). Symptoms include tip or twig wilt or dieback-leaves will be dead, brown, and desiccated but still attached to the tree (Figure 9). Vascular tissue (the interior of the twig, in cross section) may be brown and discolored. A pie-shaped mark of brown discoloration (Figure 10) is a diagnostic feature of this fungal pathogen (though it is not always seen, especially in small-diameter twigs). To control this pathogen, prune off twigs with sterilized pruners (use isopropyl alcohol to clean pruners in between cuts) well below where symptoms begin and remove diseased tissue from the field immediately. This will slow the spread of this pathogen and remove inoculum from the field. Though not a serious pathogen of olives, Botryosphaeria blight should be managed as described above where the grove serves an aesthetic purpose.

\section{PEACOCK SPOT, Spilocaea oleaginea}

This fungal leaf spot has not been seen with much frequency in Florida olive groves but is a very common fungal pathogen on olives. It is characterized by slight chlorosis (yellowing) of the leaf, with grayish-brown, round leaf spots with a lighter colored center. These leaf spots are quite distinctive compared to other pathogen symptoms. Scout trees regularly scouted for symptoms, and if you suspect disease, send a sample of 20 to 30 symptomatic leaves to the UF Plant Diagnostic Center. Photo of symptoms can be found in this factsheet: http://cesonoma.ucanr.edu/ files/37245.pdf.

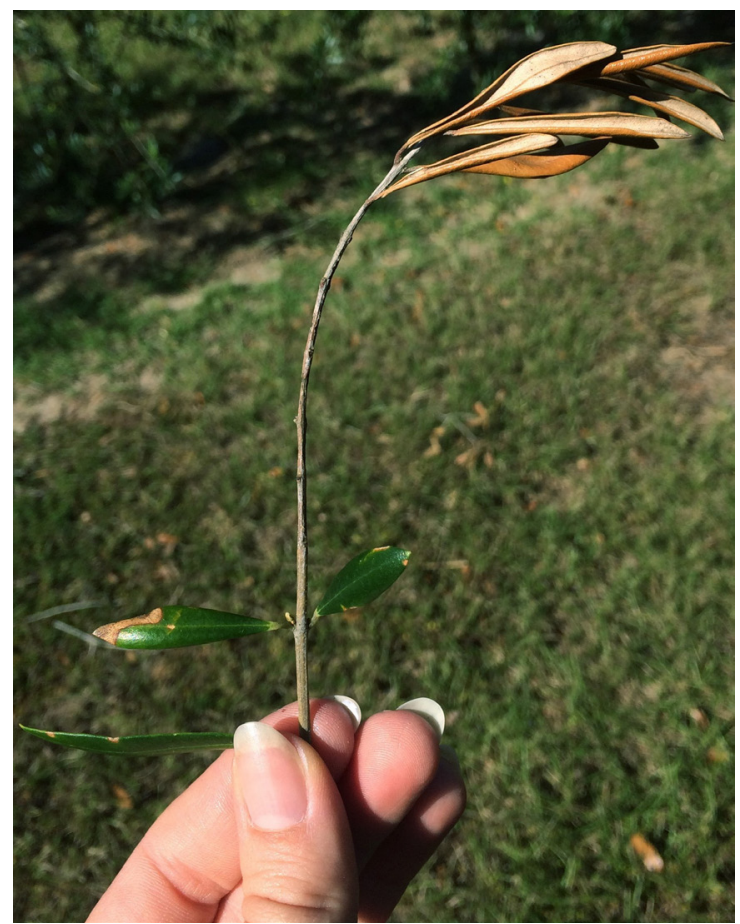

Figure 9. Symptoms of Botryosphaeria dothidea include tip or twig wilt or dieback-leaves will be dead, brown, and desiccated but still attached to the tree.

Credits: Morgan Byron

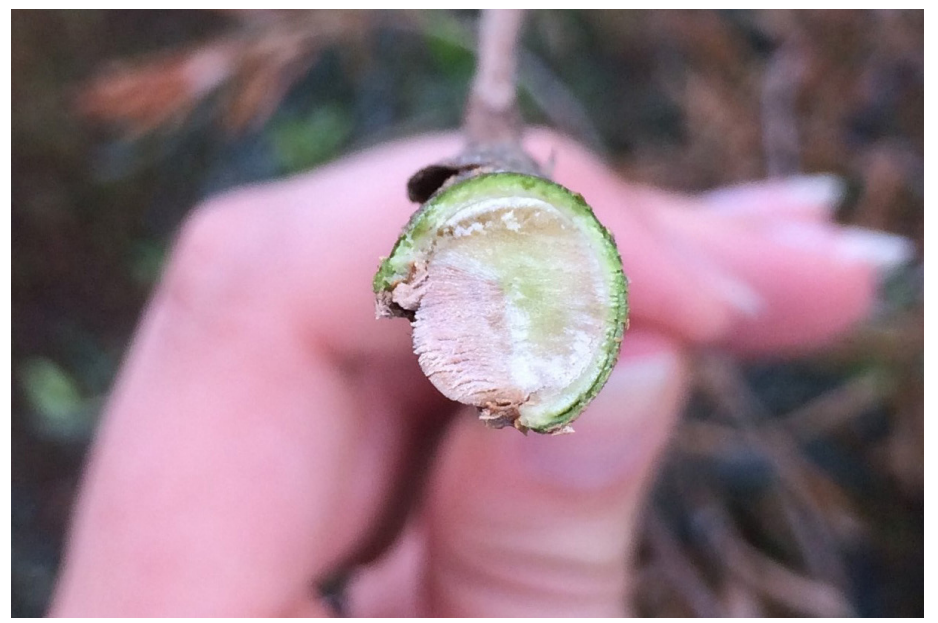

Figure 10. A pie-shaped mark of brown discoloration is a diagnostic feature of Botryosphaeria dothidea on olive in Florida. Credits: Morgan Byron

\section{Cercospora LEAF SPOT}

Different species of Cercospora are found throughout Florida on a variety of crops. This is not a commonly discussed disease of olive, but it was found in Florida in 2011 on ornamental olive (a closely related species to Olea europaea). The primary symptom is yellowing of the leaves on one half (vertically) and grayish, fuzzy-textured spore masses on the lower leaf surfaces. Photos of symptoms 
can be found in this factsheet: http://cesonoma.ucanr.edu/ files/37245.pdf.

\section{ANTHRACNOSE}

This is a common fungal disease caused by Colletotrichum sp. and has many hosts. This fungus can cause a disease called anthracnose that can be very serious on olive. It is especially damaging because it affects the fruit, causing it to become unmarketable once it ripens. Prior to ripening, symptoms are difficult to detect. Photos of symptoms can be found in Pests and Fungal Organisms Identified on Olives (Olea europaea) in Florida, available here: http://edis.ifas. ufl.edu/in1046.

\section{VERTICILLIUM WILT}

This is an important fungal disease of olive that can be found infecting many other hosts as well. It is typically characterized by wilt and dieback of branches and twigs, with discoloration of the vascular tissue (interior of the woody tissue of the tree). In olive, according to the University of California, the vascular tissue does not become discolored. To determine whether this pathogen is the source of wilt symptoms, laboratory diagnostics are required. More information can be found here.

\section{Month-by-Month Plan}

\section{January}

Fertilizer can be applied at the end of January (fertilizing before this point will result in a waste of time, labor, and money because the leaves receiving the nutrients are likely to drop during freezing events and the trees are dormant at this time, so most of the fertilizer will be lost to soil leaching). Following a soil test, use a basic fertilizer that supplies nitrogen, phosphorus, and potassium for maintaining tree health and growth. If your soil test or a leaf test of your trees reveals nutrient deficiencies, you should address them at this time, so you may need a more complete fertilizer. Boron is important for fruit set and must be applied before anthesis (opening of the flowers). Refer to the Guide to Olive Tree Nutrition in Florida, here, https://edis.ifas.ufl. edu/ag405, for complete information on boron deficiency and olive fertility needs in Florida.

\section{February}

Sample leaves for nutrient deficiencies this month to see if further correction is needed. (Refer to the Guide to Olive Tree Nutrition in Florida, here, https://edis.ifas.ufl.edu/ ag405, for information on nutrient testing.) If calcium is below $1.0-2.0 \%$, add a calcium-containing product to ensure strong flowering and fruiting. Apply before bud set for the best outcome. If also applying nitrogen at this time, calcium nitrate ( $15.5 \%$ nitrogen; $26.5 \%$ calcium) is a source of both calcium and nitrogen and can be applied via drip irrigation.

\section{March}

If your test results from the previous month indicate that your trees need it, you can apply a half-dose of the same fertilizer applied earlier in the year now. This is a good month to begin to scout for black scale insects and treat as needed to prevent spread in the grove. A good way to do this is to also look for ants that are active in the tree canopy. Monitoring with blue sticky card traps for thrips is highly recommended from March to April.

\section{April}

Flowers start to open from late February to May. Observe flowers for signs of thrips activity. Heavy rains during flowering can reduce pollination success. Avoid any activity that would wet the open flowers. Do not apply pesticides or foliar applications of nutrients when flowers are open! Begin to scout and monitor for hornworm eggs and caterpillars from this month until September.

\section{May}

If fruit is set, you can expect to experience some fruit drop at this time (leaving one or two olives on each flower spike). Dropping some fruit during very early stages of development is the trees' natural way of conserving energy and moderating productivity. If fruit drop is excessive, review what you did in February and increase the rate of calcium applied next year.

After fruit set, you can prune off branches that do not have fruit; pruning at this stage can prevent mistakenly removing branches that will be productive in the fruiting season. Never remove more than $1 / 3$ of the foliage on a tree in a given year. Removal of unproductive branches will make way for better fruit production in subsequent years. For trees with no fruit, remove branches that are protruding into the row walkways or that are crossed and rubbing against nearby branches.

\section{June}

Now (June-July) is the time to take leaf tissue samples to test for nutrients; 100 leaves from each area (two per field, separated either by cultivar or geography). Refer to the Guide to Olive Tree Nutrition in Florida, here, https://edis. ifas.ufl.edu/ag405, for information on nutrient testing. 


\section{July}

Black scale may become a problem in warm summer months. Scout for scales, ants, or sooty mold, and remove or treat infested branches.

\section{August}

Scout for pests, particularly defoliators. This is the time during which olive shootworm becomes a problem (spray Bt for control once following label directions, and again a week later if caterpillars persist).

\section{September-December}

Do not apply fertilizer until next spring. Begin tapering off irrigation in early September to allow trees to go dormant. In November (north and central Florida), chill hour accumulation is likely to begin; monitor temperature fluctuations using weather station data. If you do not have flowers or fruit next year it is important to know if you have had appropriate chill hours for floral formation. If chill hours are not the problem you will need to work to determine what issue is preventing flower formation and try to resolve the issue(s) during the next growing season.

The grant funding for the research that supported this project came from the Florida Department of Agriculture and Consumer Services Specialty Crop Block Grant Project 24064: Florida Olive Insect Pest Survey and Extension IPM Plan Development.

\section{References}

Allan, S. A., and J. L. Gillett-Kaufman. 2018. "Attraction of thrips (Thysanoptera) to colored sticky traps in a Florida olive grove." Florida Entomologist. 101(1): 61-68. https:// doi.org/10.1653/024.101.0112.

Byron, M. A., and J. L. Gillett-Kaufman. 2016a. Olive fruit fly, Bactrocera oleae (Rossi) (Insecta: Diptera: Tephritidae). University of Florida Featured Creatures. Extension Publication No. EENY 645. Available at http://entnemdept.ufl. edu/creatures/FRUIT/TROPICAL/olive_fruit_fly.htm.

Byron, M. A., and J. L. Gillett-Kaufman. 2016b. Rustic sphinx, Manduca rustica (Fabricius) (Insecta: Lepidoptera: Sphingidae). University of Florida Featured Creatures. Extension Publication No. EENY 652. Available at http:// entnemdept.ufl.edu/creatures/ORN/Manduca_rustica.htm.

Byron, M. A., J. L. Gillett-Kaufman, and S. A. Allan. 2015. Black scale, Saissetia oleae (Olivier, 1791) (Insecta: Hemiptera: Coccoidea: Coccidae). University of Florida
Featured Creatures. Extension Publication No. EENY 620. Available at http://entnemdept.ufl.edu/creatures/CITRUS/ black_scale.htm.

Connell, J. 2017. Olive Mineral Nutrition. University of California Cooperative Extension. (29 November 2017)

Collins, L., and R. H. Scheffrahn. 2001 (revised 2016). Red imported fire ant-Solenopsis invicta. UF/IFAS Featured Creature Document EENY-195. (28 November 2017)

Crane, J. H., J. Wasielewski, and C. F. Balerdi. 2018. Preparing for and recovering from hurricane and tropical storm damage to tropical fruit groves in Florida. HS1022. Gainesville: University of Florida Institute of Food and Agricultural Sciences. http://edis.ifas.ufl.edu/hs287.

Desouky, I. M., L. F. Haggag, M. M. M. Abd El-Migeed, Y. F. M. Kishk, and E. S. El-Hady. 2009. "Effect of boron and calcium nutrients sprays on fruit set, oil content and oil quality of some olive oil cultivars." World Journal of Agricultural Sciences 5: 180-185.

Elmore, W., and J. L. Gillett-Kaufman. 2017. Xylella fastidiosa and Olive Quick Decline: Symptoms and Identification of an Insect Vectored Pathogen. ENY998. Gainesville: University of Florida Institute of Food and Agricultural Sciences. http://edis.ifas.ufl.edu/in1165.

Ferguson, L. 2015. Olive production in Florida. UF/IFAS Olive Meeting 2015. http://smallfarms.ifas.ufl.edu/crops/ fruits_and_nuts/pdf/3OliveMeeting2015.pdf (1 November 2017)

Fishel, F. M. 2013. PI246. The Importance of Keeping Pesticide Records. Gainesville: University of Florida Institute of Food and Agricultural Sciences. https://edis.ifas.ufl.edu/ pi246

Gillett-Kaufman, J. L., S. A. Allan, J. H. Bosques-Mendez, and L. J. Buss. 2014. Plagas y hongos identificados en olivos (Olea europea) en Florida. ENY873. Gainesville: University of Florida Institute of Food and Agricultural Sciences. https://edis.ifas.ufl.edu/in1052.

Gillett-Kaufman, J. L., S. A. Allan, J. H. Bosques-Mendez, and L. J. Buss. 2014. Pests and fungal organisms identified on olives (Olea europaea) in Florida. ENY871. Gainesville: University of Florida Institute of Food and Agricultural Sciences. https://edis.ifas.ufl.edu/in1046. 
Gillett-Kaufman, J. L., S. A. Allan, and L. J. Buss. 2015. "Manduca rustica (Lepidoptera: Sphingidae) damage on olive (Olea europaea; Lamiales: Oleaceae) trees in Florida." Florida Entomologist 98(4): 1272-1273.

Henricot, B., C. Gorton, J. Denton, and G. Denton. 2009. "Pseudocercospora cladosporioides, the cause of leaf spot on olive, a pathogen new to the United Kingdom." Plant Pathology 58: 803.

Kitsaki, C. K., E. Andreadis, and D. L. Bouranis. 2010. "Developmental events in differentiating floral buds of four olive (Olea europaea L.) cultivars during late winter to early spring." Flora 205: 599-607.

Layton, B. 2017. Control fire ants in commercial fruits, nuts, and vegetables. Mississippi State University Extension Publication 2494 (POD-03-16) (28 November 2017)

Linn, S. E., and J. L. Gillett-Kaufman. 2016a. Olive bud mite, olive leaf and flower mite (suggested common names), Oxycenus maxwelli (Keifer, 1939) (Arachnida: Acari: Eriophyidae). University of Florida Featured Creatures. Extension Publication No. EENY 651. Available at

http://entnemdept.ufl.edu/creatures/FRUIT/TROPICAL/ olive_bud_mite.htm.

Linn, S. E., and J. L. Gillett-Kaufman. 2016b. Olive psyllid (suggested common name), Euphyllura olivina (Costa 1839) (Hemiptera: Psyllidae). University of Florida Featured Creatures. Extension Publication No. EENY 656. Available at http://entnemdept.ufl.edu/creatures/FRUIT/TROPICAL/ olive_psyllid.htm.

Lopez-Escudero, F. J., and J. Mercado-Blanco. 2011. "Verticillium wilt of olive: A case study to implement an integrated strategy to control a soil-borne pathogen." Plant Soil 344: 1-50. https://link.springer.com/content/ pdf/10.1007\%2Fs11104-010-0629-2.pdf

Malik, N. S., and J. M. Bradford. 2006. "Regulation of flowering in 'Arbequina' olives under non-chilling conditions: The effect of high daytime temperatures on blooming." International Journal of Food, Agriculture, and the Environment 4: 283-286. https://www.ars.usda.gov/ research/publications/publication/?seqNo115=188994
Mulvaney, M. J., R. Mylavarapu, P. C. Andersen, M. Thetford, and J. L. Gillett-Kaufman. 2016.

Guide to olive tree nutrition in Florida. SS-AGR-402. Gainesville: University of Florida Institute of Food and Agricultural Sciences. http://edis.ifas.ufl.edu/ag405.

Phillips, A. J. L., I. C. Rumbos, A. Alves, and A. Correia. 2004. Morphology and phylogeny of Botryosphaeria dothidea causing fruit rot of olives. Mycopathologia 159: 433-439.

Selak, G. V., S. Perica, S. G. Ban, and M. Radunic. 2011. "Reproductive success after self-pollination and crosspollination of olive cultivars in Croatia." HortScience 46: 186-191.

Spinardi, A., and D. Bassi. 2012. "Olive fertility as affected by cross-pollination and boron." ScientificWorldJournal 2012: 375631. doi: 10.1100/2012/375631

Taylor, R. K., C. N. Hale, and W. F. T. Hartill. 2001. A stem canker disease of olive (Olea europaea) in New Zealand. New Zealand Journal of Crop and Horticultural Science 29: 219-228.

Thetford, M., J. L. Gillett-Kaufman, and M. J. Mulvaney. 2015. Olives for your Florida landscape. EP 515. Gainesville: University of Florida Institute of Food and Agricultural Sciences. http://edis.ifas.ufl.edu/ep515.

Vossen, P. (Year unknown). Fertilizing olive trees. University of California Cooperative Extension. (28 November 2017).

Vossen, P. 2007. “Organic Olive Production Manual.” University of California Agriculture \& Natural Resources, California, USA. 112 pp. 